\title{
Mutations in hepatitis $B$ virus small $S$ genes predict postoperative survival in hepatocellular carcinoma
}

This article was published in the following Dove Press journal:

OncoTargets and Therapy

2 December 2016

Number of times this article has been viewed

\author{
Li Peng' \\ Guang Yang ${ }^{2}$ \\ Chensi Wu ${ }^{3}$ \\ Wenshuai Wang' \\ Jianhua $\mathrm{Wu}^{4}$ \\ Zhanjun $\mathrm{Guo}^{3}$ \\ 'Department of Hepatobiliary \\ Surgery, ${ }^{2}$ Department of Radiology, \\ ${ }^{3}$ Department of Gastroenterology and \\ Hepatology, ${ }^{4}$ Animal Center, Fourth \\ Hospital of Hebei Medical University, \\ Shijiazhuang, People's Republic \\ of China
}

\begin{abstract}
Hepatitis B virus (HBV) DNA is prone to mutations due to proofreading deficiencies of $\mathrm{HBV}$ polymerase. We have previously identified hepatocellularcarcinoma (HCC) survival-associated HBV mutations in the X, precore, and core regions. In the present study, we extended our research to assess HCC survival-associated HBV mutations in the small $S$ gene of HBV genome in 115 HCC patients including 60 patients with HBV B genotype, 52 patients with HBV C genotype, and 3 patients with other genotypes. The overfrequencies of mutations at nucleotides 529 and 735 are $8.5 \%$ and $91.5 \%$, respectively, but the distribution frequencies of these mutations are not different between HBV genotypes B and C. Mutational sites 529 (relative risk: 3.611, 95\% confidence interval [CI]: 1.414-9.221, $P=0.007$ ) and 735 (relative risk: $1.905,95 \% \mathrm{CI}$ : $1.101-3.297, P=0.021)$ were identified as statistically significant independent predictors for HCC survival by multivariate survival analysis using a Cox proportional hazards model. Moreover, the mutated 529A and 735T were associated with both short survival time and high HBV DNA load score in HCC patients. The analysis of DNA mutations in the HBV S gene may help identify HCC subgroups with poor prognosis and may provide reference for therapeutic decisions.
\end{abstract}

Keywords: HCC, HBV, survival, $S$ gene, mutations

\section{Introduction}

Hepatocellular carcinoma (HCC) is responsible for more than half a million cancerrelated deaths annually, making it the third leading cause of cancer deaths worldwide. ${ }^{1}$ A number of clinical characteristics including tumor size, tumor quantity, cell differentiation, venous invasion, and inflammation degree have been identified as predictors for $\mathrm{HCC}$, but the prognosis of HCC patients is still poor due to a high recurrence rate..$^{2-5}$

Hepatitis B virus (HBV) is a hepatotropic virus that chronically infects approximately 400 million people worldwide and is thought to be responsible for a million deaths annually. HBV infection may be associated with a large spectrum of liver diseases including chronic hepatitis, cirrhosis, and HCC. ${ }^{6,7}$ In the People's Republic of China, HBV infection is a challenging health issue with approximately 93 million people being HBV carriers and 30 million people being chronic hepatitis B patients. ${ }^{8}$ Eight geography-related HBV genotypes (genotypes A-H) have been identified with genotypes B and C predominant in eastern Asia. ${ }^{9}$

The HBV genome is a relaxed, circular, partially double-stranded DNA (rcDNA) with approximately 3,200 nucleotides and comprises four partially overlapping open reading frames (ORFs) that encode the surface protein (PreS/S), the core protein (preC/C), a polymerase (pol), and a multifunctional nonstructural protein (HBx). ${ }^{7}$ 
The PreS/S ORF has one long ORF with three in-frame "start" (ATG) codons and different aminoterminal extensions that encodes the three structurally related envelope proteins termed large, middle, and short proteins. The small S protein (HBsAg) contains 226 amino acids (aa), the middle protein $($ PreS2 $+\mathrm{S})$ contains an extra $\mathrm{N}$-terminal extension of 55 aa, whereas the large protein $($ PreS1 $1+$ PreS2 $+\mathrm{S})$ has a further extensional N-terminal aa of 108 or $119 .{ }^{10} \mathrm{HBV}$ DNA is prone to mutations due to the proofreading deficiencies of HBV polymerase. ${ }^{11,12}$ The HCC risk-associated HBV mutations have been well studied in HBV-related HCC (HBV-HCC) patients in recent years, ${ }^{13-18}$ furthermore, we and other researchers have found the prognostic value of the $\mathrm{X}$ and PreC/C region mutations for $\mathrm{HCC}$ outcome. ${ }^{19-21}$ The potential role of $\mathrm{HBV}$ preS mutations on $\mathrm{HCC}$ pathogenesis had been identified previously; ${ }^{7,22,23}$ we have now extended our research to assess HCC survival-associated HBV mutations in small $S$ gene.

\section{Materials and methods}

\section{Tissue specimens and DNA extraction}

$\mathrm{HBV}-\mathrm{HCC}$ tissue specimens were collected from patients who underwent tumor resection in the Department of Hepatobiliary Surgery in the Fourth Hospital of Hebei University between 2007 and 2010. The Wizard Genomic DNA extraction kit (Promega, Madison, WI, USA) was used to extract genomic DNA. This study and all procedures were supervised and approved by the Human Tissue Research Committee of the Fourth Hospital of Hebei Medical University. Written informed consent was obtained from all patients.

\section{Virological assay}

The HBV DNA concentration in the HBV-HCC tissue was quantified as copies per microgram of genomic DNA with ABI 7300 TaqMan platform (Life Technologies, Carlsbad, CA, USA) by real-time PCR. HBV genotypes were determined by multiplex-PCR as described previously. ${ }^{18}$ The DNA sequences flanking the small $\mathrm{S}$ region were amplified with the primer pairs listed in Table 1 according to the NCBI database

Table I Primer pairs used in amplifying and sequencing the small $S$ gene

\begin{tabular}{lll}
\hline Primers & Nucleotide sequences $\left(\mathbf{5}^{\prime} \rightarrow \mathbf{3}^{\prime}\right)$ & Positions \\
\hline SI-F & CCTCTAAGAGACAGTCATCC & 3,178 \\
SI-R & AGAAGATGAGGCATAGCAGC & 434 \\
S2-F & TGGCTATCGCTGGATGTGTC & 364 \\
S2-R & GATGTTGTACAGACTTGGCC & 778 \\
S3-F & TGTTCAGTGGTTCGTAGGGC & 691 \\
S3-R & GCGAGAAAGTGAAAGCCTGC & 1,102 \\
\hline
\end{tabular}

Notes: SI-S3 represent primer pairs used for $S$ gene amplication; $F$ represents forward primer; and $\mathrm{R}$ represents reverse primer. (http://www.ncbi.nlm.nih.gov/genome/5536). Cyclic sequencing was performed with a BigDye Terminator v3.1 Cycle Sequencing Kit (Life Technologies) by ABI PRISM 3100 Genetic Analyzer (Life Technologies). Mutations were confirmed by repeating the analysis on both the strands.

\section{Statistical analysis}

Survival curves were plotted with the log-rank test using Kaplan-Meier method. Cox proportional hazards model was used for multivariate survival analysis and $\chi^{2}$ test to analyze dichotomous values among the genotypes and HBV DNA copy numbers. All statistical analyses were performed using SPSS 18.0 software package (IBM Corporation, Armonk, NY, USA), and a $P$-value $<0.05$ was considered statistically significant.

\section{Results \\ Clinical characteristics of HBV-HCC patients}

A total of $115 \mathrm{HBV}-\mathrm{HCC}$ patients including 60 patients with $\mathrm{B}$ genotype, 52 patients with $\mathrm{C}$ genotype, 2 patients with $\mathrm{D}$ genotype, and 1 patient with $\mathrm{A}+\mathrm{C}$ genotype were enrolled in this study. The relationships between the clinical characteristics and postoperative overall survival in HBVHCC patients were analyzed with the log-rank test using Kaplan-Meier method. The portal vein thrombosis, tumor size, tumor stage, and HBV DNA load score were identified for their association with survival by univariate analysis (Table 2). After adjusting for clinical characteristics with the Cox proportional hazards model, the portal vein thrombosis and HBV load score were identified as independent predictors of postoperative survival in HBV-HCC patients.

\section{Mutation of small $S$ gene is associated with postoperative survival in $\mathrm{HCC}$ patients}

The DNA sequences flanking the small $S$ gene were sequenced in $47 \mathrm{HBV}-\mathrm{HCC}$ patients. Firstly, a total of 88 mutations were identified (Figure 1). The mutation sites with mutation distribution frequency higher than $5 \%$ were analyzed for their association with HCC survival by Kaplan-Meier method for patients with HBV genotypes B and C (Table 3). The potentially HCC survival-associated mutations sites of 529 and 735 were further analyzed in the remaining $\mathrm{HCC}$ patients; these two sites were identified for their association with HCC survival (Figure 2). After adjusting for clinical characteristics with the Cox proportional hazards model, the mutated 529A and 735T were associated with short survival time of HCC patients: 529 (RR: 3.611, 
Table 2 Univariate and multivariate analyses of clinical characteristics associated with postoperative survival in HBV-HCC patients

\begin{tabular}{|c|c|c|c|c|c|c|}
\hline \multirow[t]{2}{*}{ Factors } & \multirow[t]{2}{*}{ Cases (n) } & \multirow{2}{*}{$\begin{array}{l}\text { 3-year survival } \\
\text { rate }(\%)\end{array}$} & \multirow{2}{*}{$\begin{array}{l}\text { Univariate } \\
\text { analysis ( } P \text {-value) }\end{array}$} & \multicolumn{3}{|c|}{ Multivariate analysis } \\
\hline & & & & $P$-value & $\mathbf{R R}$ & $95 \% \mathrm{Cl}$ \\
\hline Age (years) & & & 0.639 & 0.305 & 0.739 & $0.415-1.316$ \\
\hline$\leq 55$ & 60 & 45.0 & & & & \\
\hline$>55$ & 55 & 49.1 & & & & \\
\hline Gender & & & 0.534 & 0.133 & 1.866 & $0.827-4.211$ \\
\hline Male & 101 & 46.5 & & & & \\
\hline Female & 14 & 50 & & & & \\
\hline Child-Pugh classification & & & 0.263 & 0.101 & 2.201 & $0.858-5.649$ \\
\hline A & 106 & 48.1 & & & & \\
\hline B & 9 & 33.3 & & & & \\
\hline Genotype & & & 0.722 & 0.96 & 0.988 & $0.619-1.579$ \\
\hline B & 60 & 48.3 & & & & \\
\hline C & 52 & 44.2 & & & & \\
\hline Other genotype & 3 & 66.7 & & & & \\
\hline Tumor number & & & 0.551 & 0.098 & 1.83 & $0.895-3.744$ \\
\hline Single & 97 & 47.4 & & & & \\
\hline Multiple & 18 & 44.4 & & & & \\
\hline Portal vein thrombosis & & & 0.000 & 0.000 & 3.516 & $1.787-6.919$ \\
\hline Present & 15 & 6.7 & & & & \\
\hline Absent & 100 & 53 & & & & \\
\hline TNM classification & & & 0.004 & $0.84 I$ & 1.084 & $0.494-2.379$ \\
\hline I & 46 & 65.2 & & & & \\
\hline II & 65 & 35.4 & & & & \\
\hline III & 4 & 25.0 & & & & \\
\hline Size of tumor (diameter) & & & 0.000 & 0.059 & 2.137 & $0.972-4.698$ \\
\hline$\leq 5 \mathrm{~cm}$ & 51 & 64.7 & & & & \\
\hline$>5 \mathrm{~cm}$ & 64 & 32.8 & & & & \\
\hline HBV DNA ${ }^{a}$ & & & 0 & 0.042 & 0.52 & $0.277-0.975$ \\
\hline$\geq 6 \times 10^{8}$ & 66 & 31.8 & & & & \\
\hline$<6 \times 10^{8}$ & 49 & 67.3 & & & & \\
\hline
\end{tabular}

Note: aDefined as copies per microgram of genomic DNA from HCC tissue (copies/ $\mu \mathrm{g})$.

Abbreviations: $\mathrm{Cl}$, confidence interval; $\mathrm{HBV}$, hepatitis $\mathrm{B}$ virus; $\mathrm{HBV}-\mathrm{HCC}$, hepatitis $\mathrm{B}$ virus related hepatocellular carcinoma; RR, relative risk.

95\% confidence interval [CI]: 1.414-9.221, $P=0.007) ; 735$ (RR: $1.905,95 \% \mathrm{CI}: 1.101-3.297, P=0.021)$. The overfrequencies of mutations at nucleotide 529 and 735 were $8.5 \%$ and $91.5 \%$, respectively, but the distribution frequencies of these mutations were not different between HBV genotypes $\mathrm{B}$ and $\mathrm{C}$. We evaluated the relationships between HBV replication and these two mutated sites, and the mutations were associated with higher HBV DNA load score (Table 4).

\section{Discussion}

$\mathrm{HBV}$ has a mutation rate that is more than 10 -fold higher than that of other DNA viruses due to the deficiency of the proofreading function for HBV polymerase. . $^{71,12}$ Accumulation of mutations reflects both the activity of virus infection and the strength of the immune response. Some of these mutations could provide a survival advantage for HBV while the others are detrimental. ${ }^{7}$ The HBV mutations are clustered in a particular region of the $\mathrm{HBV}$ genome such as the basal core promoter (BCP)/preCore region and the preS/S region. ${ }^{24} \mathrm{We}$ have identified previously the HBV-HCC survival-associated HBV mutations in the $\mathrm{X}$ protein region and preCore regions. ${ }^{20,21}$ Now we have extended our research to evaluate the mutations in the HBV DNA sequences flanking the small $S$ gene and

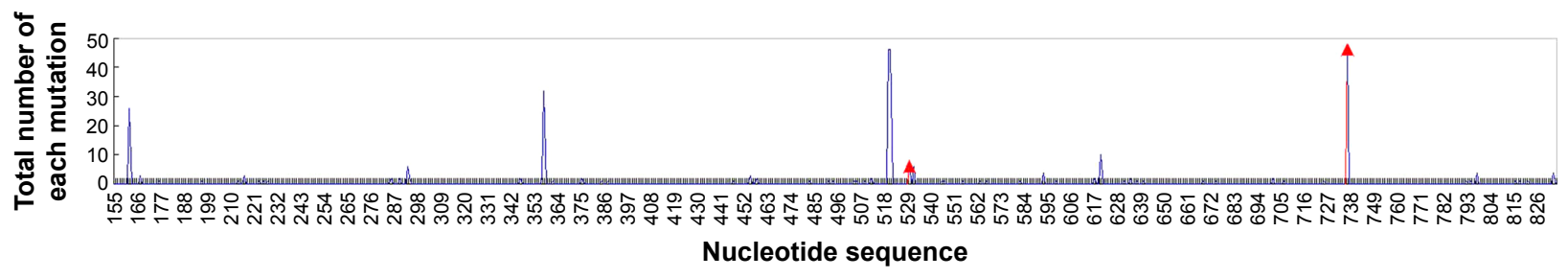

Figure I Total mutations of each nucleotide in the small S gene. The triangles represent mutations sites of 529 and 735 potentially associated with $\mathrm{HBV}$ - $\mathrm{HCC}$ survival. Abbreviation: HBV-HCV, hepatitis B virus related hepatocellular carcinoma. 
Table 3 Univariate analysis of small $S$ gene mutations associated with postoperative survival in patients HBV-HCC

\begin{tabular}{|c|c|c|c|c|}
\hline Factors & $\begin{array}{l}\text { No of } \\
\text { cases }\end{array}$ & $\begin{array}{l}\text { 3-year survival } \\
\text { rate (\%) }\end{array}$ & $\begin{array}{l}\text { Univariate } \\
\text { analysis } \\
P \text {-value }\end{array}$ & $\begin{array}{l}\text { Amino acid } \\
\text { substitution }\end{array}$ \\
\hline 162 & & & 0.580 & Yes, Ser $\rightarrow$ Asn $(3)^{c}$ \\
\hline$A^{a}$ & 26 & 30.8 & & \\
\hline $\mathrm{G}^{\mathrm{b}}$ & 21 & 42.9 & & \\
\hline 216 & & & 0.851 & Yes, Leu $\rightarrow \operatorname{Ser}(20)^{c}$ \\
\hline $\mathrm{T}^{\mathrm{a}}$ & 44 & 36.4 & & \\
\hline$C^{b}$ & 3 & 33.3 & & \\
\hline 293 & & & 0.572 & Yes, Thr $\rightarrow$ Ala $(46)^{c}$ \\
\hline $\mathrm{G}^{\mathrm{a}}$ & 6 & 16.7 & & \\
\hline$A^{b}$ & 41 & 39.0 & & \\
\hline 357 & & & 0.704 & Yes, Thr $\rightarrow \| l e(68)^{c}$ \\
\hline $\mathrm{C}^{\mathrm{a}}$ & 15 & 33.3 & & \\
\hline $\mathrm{T}^{\mathrm{b}}$ & 32 & 35.7 & & \\
\hline 454 & & & 0.447 & No \\
\hline $\mathrm{C}^{\mathrm{a}}$ & 44 & 34.1 & & \\
\hline $\mathrm{T}^{\mathrm{b}}$ & 3 & 66.7 & & \\
\hline 529 & & & 0.007 & No \\
\hline $\mathrm{G}^{\mathrm{a}}$ & 41 & 41.5 & & \\
\hline$A^{b}$ & 6 & 0.0 & & \\
\hline 531 & & & 0.988 & Yes, Ile $\rightarrow \operatorname{Thr}(126)^{c}$ \\
\hline $\mathrm{T}^{\mathrm{a}}$ & 42 & 35.7 & & \\
\hline$C^{b}$ & 5 & 40.0 & & \\
\hline 592 & & & 0.654 & No \\
\hline$C^{a}$ & 43 & 34.9 & & \\
\hline $\mathrm{T}^{\mathrm{b}}$ & 4 & 50.0 & & \\
\hline 619 & & & 0.966 & No \\
\hline $\mathrm{C}^{\mathrm{a}}$ & 37 & 35.1 & & \\
\hline $\mathrm{T}^{\mathrm{b}}$ & 10 & 40.0 & & \\
\hline 735 & & & 0.029 & Yes, $\mathrm{Ala} \rightarrow \mathrm{Val}(194)^{\mathrm{c}}$ \\
\hline$C^{a}$ & 4 & 100.0 & & \\
\hline $\mathrm{T}^{\mathrm{b}}$ & 43 & 30.2 & & \\
\hline 796 & & & 0.827 & No \\
\hline $\mathrm{T}^{\mathrm{a}}$ & 43 & 37.2 & & \\
\hline $\mathrm{G}^{\mathrm{b}}$ & 4 & 25.0 & & \\
\hline 799 & & & 0.517 & No \\
\hline $\mathrm{A}^{\mathrm{a}}$ & 43 & 34.9 & & \\
\hline $\mathrm{G}^{\mathrm{b}}$ & 4 & 50.0 & & \\
\hline 832 & & & 0.189 & No \\
\hline $\mathrm{T}^{\mathrm{a}}$ & 43 & 37.2 & & \\
\hline$C^{b}$ & 4 & 25.0 & & \\
\hline
\end{tabular}

Notes: ${ }^{\text {RRepresents wild allele; }{ }^{\mathrm{b}} \text { Represents mutant allele. }{ }^{\mathrm{C}} \text { The numbers in }}$ parentheses represent the amino acid position in the $S$ protein.

Abbreviations: Ala, alanine; Asn, asparagine; HBV-HCC, hepatitis B virus related hepatocellular carcinoma; Ile, isoleucine; Leu, leucine; Ser, serine; Thr, threonine; Val, valine.

identified two mutations associated with HBV-HCC survival by multivariate analysis.

The specific $\mathrm{preS} / \mathrm{S}$ gene mutations may induce both the intracellular accumulation of envelope proteins in the endoplasmic reticulum (ER), resulting in liver damage, and the activation of ER stress-signaling pathways, resulting in oxidative DNA damage and genomic instability; all these contribute to HCC development. ${ }^{7,23,25,26}$ The "a" determinant, that is the immunodominant determinant for the anti-HBs neutralization, is located in the aa $99-170$ of the S protein. ${ }^{10,27}$ Nonsense
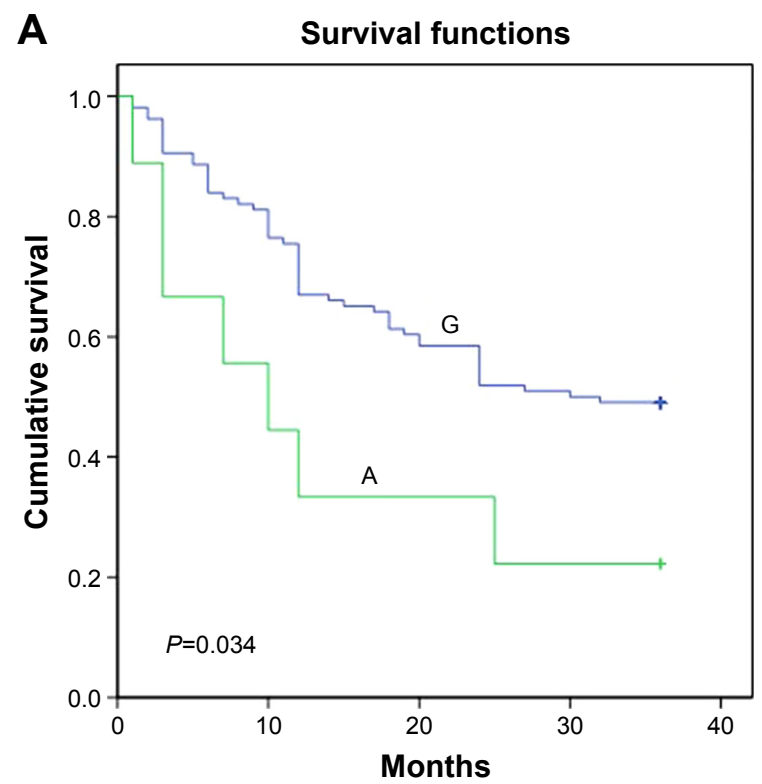

B

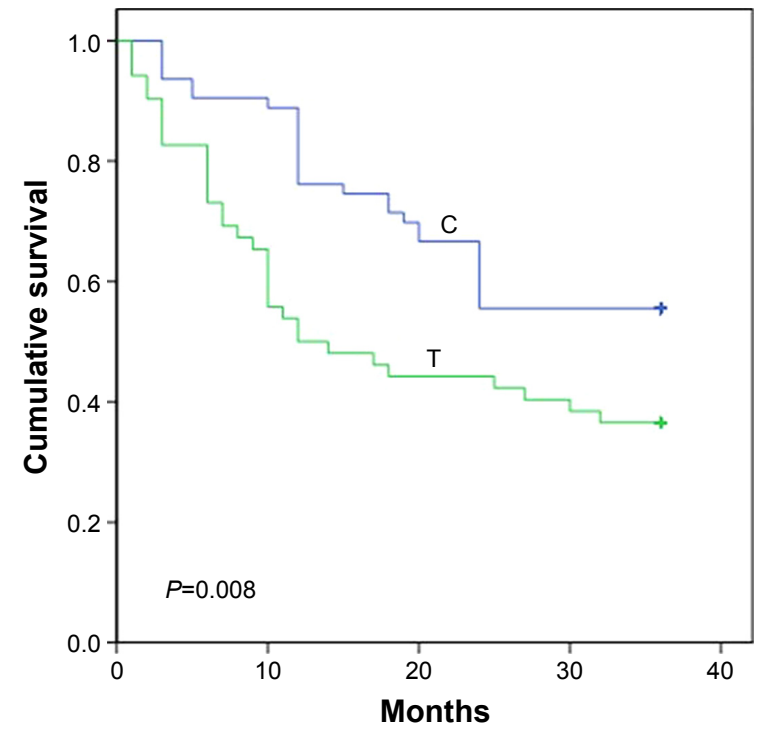

Figure 2 Association of nucleotide sites 529 and 735 in the small S gene with HBVHCC survival. (A) 529 nucleotide site and (B) 735 nucleotide site.

Abbreviation: $\mathrm{HBV}-\mathrm{HCV}$, hepatitis $B$ virus related hepatocellular carcinoma.

Table 4 Relationship between HBV DNA load and small $S$ gene mutations in HBV-HCC patients

\begin{tabular}{|c|c|c|c|c|}
\hline \multirow[t]{2}{*}{$\begin{array}{l}\text { Nucleotide } \\
\text { sites }\end{array}$} & \multirow[t]{2}{*}{ Variants } & \multicolumn{2}{|c|}{$\begin{array}{l}\text { HBV DNA load } \\
\text { (copies } / \mu \mathrm{g})\end{array}$} & \multirow[t]{2}{*}{$P$-value } \\
\hline & & $<6 \times 10^{8}$ & $\geq 6 \times 10^{8}$ & \\
\hline \multirow[t]{3}{*}{529} & & & & 0.007 \\
\hline & G & 49 & 57 & \\
\hline & $A$ & 0 & 9 & \\
\hline \multirow[t]{3}{*}{735} & & & & 0.000 \\
\hline & C & 37 & 26 & \\
\hline & $\mathrm{T}$ & 12 & 40 & \\
\hline
\end{tabular}

Abbreviations: $\mathrm{HBV}$, hepatitis B virus; HBV-HCC, HBV-related hepatocellular carcinoma. 
mutations in the "a" determinant induce antigenically modified S proteins that may escape from the specific antiHBs neutralizing antibody. ${ }^{28-30}$ The 529 mutation site was located in the "a" determinant region; this mutation does not induce aa substitution in the $S$ gene, but the complete overlapping of PreS/S ORF with polymerase has made it possible to induce aa substitution of rtD134N in the HBV polymerase which may result in an altered function of the HBV polymerase so as to effect the viral replication. Our data did show that the 529G-A mutation might increase HBV DNA replication. Laboratory-based functional study for the role of $735 \mathrm{C}-\mathrm{T}$ which induces Ala-Val substitution on HCC development should be performed. The other mutations in the $S$ gene were also analyzed for their association with the viral DNA load score, but statistical difference could not be found. These data implied that the 529- and 735-mutation-related alterations of the viral DNA scores should be responsible, at least partly, for the outcome of HCC.

In conclusion, we found survival-associated $S$ gene mutations in HCC patients. The detection of outcome-associated HBV variants may help identify those HCC patients with poor prognosis for appropriate treatment.

\section{Acknowledgment}

This work was supported by the Key Basic Research Program of Hebei (14967713D).

\section{Disclosure}

The authors report no conflicts of interest in this work.

\section{References}

1. Gomaa AI, Khan SA, Toledano MB, Waked I, Taylor-Robinson SD. Hepatocellular carcinoma: epidemiology, risk factors and pathogenesis. World J Gastroenterol. 2008;14(27):4300-4308.

2. Maki A, Kono H, Gupta M, et al. Predictive power of biomarkers of oxidative stress and inflammation in patients with hepatitis $\mathrm{C}$ virus-associated hepatocellular carcinoma. Ann Surg Oncol. 2007;14(3):1182-1190.

3. Okada S, Shimada K, Yamamoto J, et al. Predictive factors for postoperative recurrence of hepatocellular carcinoma. Gastroenterology. 1994; 106(6): 1618-1624.

4. Minagawa M, Makuuchi M, Takayama T, Kokudo N. Selection criteria for repeat hepatectomy in patients with recurrent hepatocellular carcinoma. Ann Surg. 2003;238(5):703-710.

5. Wang C, Zhang F, Fan H, et al. Sequence polymorphisms of mitochondrial D-loop and hepatocellular carcinoma outcome. Biochem Biophys Res Commun. 2011;406(3):493-496.

6. Dienstag JL. Hepatitis B virus infection. N Engl J Med. 2008;359(14): $1486-1500$.

7. Pollicino T, Cacciola I, Saffioti F, Raimondo G. Hepatitis B virus PreS/S gene variants: pathobiology and clinical implications. $J$ Hepatol. 2014;61(2):408-417.

8. Lu FM, Zhuang H. Management of hepatitis B in China. Chin Med J (Engl). 2009;122(1):3-4.

9. Yu MC, Yuan JM, Govindarajan S, Ross RK. Epidemiology of hepatocellular carcinoma. Can J Gastroenterol. 2000;14(8):703-709.
10. Seeger C, Mason WS. Hepatitis B virus biology. Microbiol Mol Biol Rev. 2000;64(1):51-68.

11. Yang HI, Yeh SH, Chen PJ, et al; REVEAL-HBV Study Group. Associations between hepatitis B virus genotype and mutants and the risk of hepatocellular carcinoma. J Natl Cancer Inst. 2008;100(16): 1134-1143.

12. Tsai WL, Chung RT. Viral hepatocarcinogenesis. Oncogene. 2010; 29(16):2309-2324.

13. Chan HL, Tse $\mathrm{CH}$, Mo F, et al. High viral load and hepatitis B virus subgenotype ce are associated with increased risk of hepatocellular carcinoma. J Clin Oncol. 2008;26(2):177-182.

14. Yu MW, Yeh SH, Chen PJ, et al. Hepatitis B virus genotype and DNA level and hepatocellular carcinoma: a prospective study in men. J Natl Cancer Inst. 2005;97(4):265-272.

15. Liu CJ, Chen BF, Chen PJ, et al. Role of hepatitis B viral load and basal core promoter mutation in hepatocellular carcinoma in hepatitis B carriers. J Infect Dis. 2006;193(9):1258-1265.

16. Lin CL, Liu CH, Chen W, et al. Association of pre-S deletion mutant of hepatitis B virus with risk of hepatocellular carcinoma. J Gastroenterol Hepatol. 2007;22(7):1098-1103.

17. Kao JH, Chen PJ, Lai MY, Chen DS. Basal core promoter mutations of hepatitis B virus increase the risk of hepatocellular carcinoma in hepatitis B carriers. Gastroenterology. 2003;124(2):327-334.

18. Kim DW, Lee SA, Hwang ES, Kook YH, Kim BJ. Naturally occurring precore/core region mutations of hepatitis B virus genotype $\mathrm{C}$ related to hepatocellular carcinoma. PLoS One. 2012;7(10):e47372.

19. Yeh CT, So M, Ng J, et al. Hepatitis B virus-DNA level and basal core promoter A1762T/G1764A mutation in liver tissue independently predict postoperative survival in hepatocellular carcinoma. Hepatology. 2010;52(6):1922-1933.

20. Xie Y, Liu S, Zhao Y, Guo Z, Xu J. X protein mutations in hepatitis B virus DNA predict postoperative survival in hepatocellular carcinoma. Tumour Biol. 2014;35(10):10325-10331.

21. Xie Y, Liu S, Zhao Y, et al. Precore/core region mutations in hepatitis B virus DNA predict postoperative survival in hepatocellular carcinoma. PLoS One. 2015;10(7):e0133393.

22. Raimondo G, Costantino L, Caccamo G, et al. Non-sequencing molecular approaches to identify preS2-defective hepatitis B virus variants proved to be associated with severe liver diseases. J Hepatol. 2004; 40(3):515-519.

23. Wang HC, Huang W, Lai MD, Su IJ. Hepatitis B virus pre-S mutants, endoplasmic reticulum stress and hepatocarcinogenesis. Cancer Sci. 2006;97(8):683-688.

24. Locarnini S, McMillan J, Bartholomeusz A. The hepatitis B virus and common mutants. Semin Liver Dis. 2003;23(1):5-20.

25. Hagen TM, Huang S, Curnutte J, et al. Extensive oxidative DNA damage in hepatocytes of transgenic mice with chronic active hepatitis destined to develop hepatocellular carcinoma. Proc Natl Acad Sci USA. 1994;91(26):12808-12812.

26. Wang LH, Huang W, Lai MD, Su IJ. Aberrant cyclin A expression and centrosome overduplication induced by hepatitis B virus pre-S2 mutants and its implication in hepatocarcinogenesis. Carcinogenesis. 2012; 33(2):466-472.

27. Norder H, Couroucé AM, Magnius LO. Molecular basis of hepatitis B virus serotype variations within the four major subtypes. J Gen Virol. 1992;73(Pt 12):3141-3145.

28. Weber $\mathrm{B}$. Genetic variability of the $\mathrm{S}$ gene of hepatitis $\mathrm{B}$ virus: clinical and diagnostic impact. J Clin Virol. 2005;32(2):102-112.

29. Pawlotsky JM. The concept of hepatitis B virus mutant escape. J Clin Virol. 2005;34(Suppl 1):S125-S129.

30. Yamamoto K, Horikita M, Tsuda F, et al. Naturally occurring escape mutants of hepatitis B virus with various mutations in the $\mathrm{S}$ gene in carriers seropositive for antibody to hepatitis B surface antigen. $J$ Virol. 1994;68(4):2671-2676. 


\section{Publish your work in this journal}

OncoTargets and Therapy is an international, peer-reviewed, open access journal focusing on the pathological basis of all cancers, potential targets for therapy and treatment protocols employed to improve the management of cancer patients. The journal also focuses on the impact of management programs and new therapeutic agents and protocols on

patient perspectives such as quality of life, adherence and satisfaction. The manuscript management system is completely online and includes a very quick and fair peer-review system, which is all easy to use. Visit http://www.dovepress.com/testimonials.php to read real quotes from published authors.

Submit your manuscript here: http://www.dovepress.com/oncotargets-and-therapy-journal 